\title{
Moisture Content Change of Korean Red Pine Logs During Air Drying: I. Effective Air Drying Days in Major Regions in Korea ${ }^{1}$ (⿺辶尺)
}

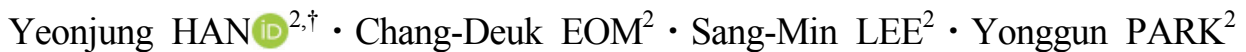

\begin{abstract}
Air drying depends on species, density, dimension of wood, the geographical location of the air drying yard, and the meteorological factors of air drying site. If there are four seasons with large difference in temperature and humidity like in Korea, the research of the meteorological factors is required in air drying site. In this study, effective air drying days (EADD) of 24 regions in Korea were calculated by using the average monthly temperature, relative humidity, and wind speed. The EADD in 24 regions in Korea was ranged from 239 days to 291 days, with an average 265 days. This result is 5 days increased compared to the average of EADD calculated using the meteorological factors from 1955 to 1984. The results of multiple regression analysis on the EADD and meteorological factors showed that EADD affected in the order of temperature, relative humidity, and wind speed. As a result of dividing Korea into 4 zones of EADD, the zones of EADD were moved northward compared to previous study due to global warming. As basic data for predicting the moisture content (MC) distribution of Korean red pine logs during air drying conducted in Seoul, the average monthly temperature, relative humidity and wind speed for three years from 2016 to 2018 were presented, and the corresponding changes of the equilibrium MC were analyzed.
\end{abstract}

Keywords: air drying, effective air drying days, zone of effective air drying days, air drying calendar, meteorological factor

\section{INTRODUCTION}

Air drying defines a method of drying green wood by stacking it in a air drying yard while exposing it naturally to an open-atmosphere (Jung et al., 2005). Compared to the artificial drying, air drying has advantages of barely having any initial facility fees and energy costs, while air drying has disadvantages of being highly impacted by its location and the climate, requiring larger drying yards, and being unable to dry below the atmospheric moisture level. Because air drying should be considered factors like species, density, dimensions of woods, geographical location and meteorological factors of the drying site, it is difficult to predict air drying time required for logs and lumbers with different moisture content (MC). Location like

${ }^{1}$ Date Received October 11, 2019, Date Accepted October 28, 2019

2 Department of Forest Products, National Institute of Forest Science, 57 Heogi-ro, Dondaemun-gu, Seoul, 02455, Republic of Korea

$\dagger$ Corresponding author: Yeonjung HAN (e-mail: yeonjungh@korea.kr, ORCID: 0000-0002-0962-5918) 
Korea where there are four distinct seasons, time required for air drying is varied in the season initiating air drying due to the temperature difference between summer and winter (Simpson and Hart, 2001).

Effective air drying days (EADD) is numerical days per a month appropriate for air drying based on the meteorological factor (Rietz, 1972), and when applied, air drying calendar can be presented for different regions. Korean and international studies related to air drying and EADD is subjected to the softwood and hardwood samples with the thickness of $50 \mathrm{~mm}$ or below. In Korea, there are studies on analyzing the time required for taun lumbers to reach $20 \% \mathrm{MC}$ and obtaining air drying calendar (Jung, 1985), calculating EADD among 24 regions in Korea and categorizing 4 zones based on the result (Jung and Park, 1986), calculating and comparing moisture indexes for climate classification using the meteorological data from 82 regions in Korea (Ra, 2018), and suggesting a regression equation for monitoring the $\mathrm{MC}$ in Korean red pine and pitch pine wood (Jung et al., 1986). In U.S., there are studies on measuring air drying time for American beech with a thickness of $25 \mathrm{~mm}-50 \mathrm{~mm}$ (Peck, 1954), ponderosa pine (Peck et al. 1956), sugar maple (Peck, 1957), northern red oak (Peck, 1959), and Douglar fir and yellow poplar (Denig and Wengert, 1982), based on thickness of lumbers, timing of stacking, locations of air drying yards, and meteorological factor. Moreover, the study on categorizing U.S. regions based on the average of 'growing degree days' suggested by USDA in 1975 and measuring the required time for air drying from each region was performed (Rietz, 1972; McMillen and Wengert, 1978).

This study is a pilot study for analyzing changes in MC for Korean red pine logs during air drying, and the EADD for each region was calculated using the 30 -years of meteorological data provided by Korea Meteorological Administration (http://data.kma.go.kr) such as temperature, relative humidity, and wind velocity from 24 different regions in Korea. The result was compared with the study from 1986 (Jung and Park, 1986) to examine the effect of climate change in EADD.

\section{MATERIALS and METHODS}

\subsection{Collecting meteorological data from the 24 regions in Korea}

The study used the data from Korea Meteorological Administration in order to collect meteorological factors like temperature, relative humidity, and wind speed, to examine their effects on MC level in air drying wood. Korea Meteorological Administration provides an overall statistical data on temperature, precipitation, wind speed, wind direction, humidity, and the amount of solar radiation from Korea's main regions. In this study, in order to parallelly compare the EADD study result from the 1986 (Jung and Park, 1986) with the recent changes in the 30-years of EADD of main regions in Korea, average monthly temperature, relative humidity, wind speed were collected from the same 24 regions in Korea (Sokcho, Chuncheon, Gangneung, Seoul, Incheon, Ulleung-do, Suwon, Seosan, Cheongju, Daejeon, Chupungnyeong, Pohang, Gunsan, Daegu, Jeonju, Ulsan, Gwangju, Busan, Tongyeong, Mokpo, Yeosu, Jeju, Seogwipo, Jinju) which were used in the precedent study.

\subsection{Method of calculating EADD}

EADD was calculated using the meteorological data provided from Korean Meteorological Administration. The EADD calculation was obtained using the method provided by USDA Forest Service Forest Products Laboratory (Reitz, 1972). An appropriate monthly air drying days were hypothesized as 30 days, and two days were deducted from it when the average summer (June, July, August) monthly relative humidity is 5\% or more higher than the yearly average and the average 
summer monthly wind speed was $1.8 \mathrm{~m} / \mathrm{s}$ or more less than the yearly average. Five days are deducted when the average temperature of spring (March, April, May), fall (September, October, and November), and winter (December, January, February), is $5.5^{\circ} \mathrm{C}$ less than those of the three summer months; two days were deducted when the average relative humidity is $5 \%$ or more higher than the yearly average relative humidity, or when the average wind speed is $1.8 \mathrm{~m} / \mathrm{s}$ or more less than the yearly average wind speed. When the data from both relative humidity and wind speed are satisfying the above conditions, total of four days are deducted (Jung and Park, 1986).

\subsection{Categorization of regional EADD zone}

EADD zones in Korea can be categorized into 4 zones based on the number of EADD: the first zone is the zone with the EADD of below 250 days; the second zone is the EADD range from 250 - 259 days; the third zone is the EADD range from $260-269$ days; and the fourth zone is the EADD of 270 days or above (Jung and Park, 1986). This study categorizes EADD zones using the EADD data from the 24 regions in Korea based on the recent 30 years of meteorological data, and compares this data with the past 30 years of EADD zone.

\subsection{Calculation of equilibrirum moisture content based on the climate changes in Seoul}

In order to measure the change in MC for 16 samples of air air drying Koren red pine log containing the initial MC range from $28-83 \%$ and the diameter range from $310-510 \mathrm{~mm}$, provisional air drying site is installed on June 2016 in National Institute of Forest Science located in Dongdaemungu, Seoul. Upon installation of the air drying site, equilibrirum MC was calculated based on the average monthly temperature, relative humidity, and wind speed from 2016 to 2018 . The equation (1) was used to calculate the data, based on the Hailwood-Horrobin's adsorption model (Simpson, 1973).

$$
E M C=\frac{1800}{W}\left(\frac{K h}{1-K h}+\frac{K_{1} K h+2 K_{1} K_{2} K^{2} h^{2}}{1+K_{1} K h+K_{1} K_{2} K^{2} h^{2}}\right) \cdots \cdots(1)
$$

where, $\mathrm{EMC}=$ equilibrium moisture content $(\%)$; $\mathrm{h}=$ relative humidity expressed in decimal form (\%/100); $\mathrm{W}, \mathrm{K}, \mathrm{K}_{1}, \mathrm{~K}_{2}=$ temperature dependent parameters.

\section{RESULTS and DISCUSSION}

\subsection{Surveying EADD of the main regions in Korea}

On Table 1, EADD, standard deviation, air drying calendars of 24 regions in Korea is exhibited. The data was calculated on 1986 utilizing meteorological factors like average monthly temperature, relative humidity, and wind speed (Jung and Park, 1986). This data was calculated using the monthly average of regional meteorological factors range from 18 - 30 period of years, and each year of data measurement is stated below Table 1. Among 24 regions of Korea, the average EADD was 260 days, the maximum was 288 days (Seogwipo), the minimum EADD was 237 days (Chuncheon). EADD was affected the most by average temperature. Although relative humidity periodically influenced on September, wind speed had no impact on the EADD.

On Table 2, EADD of 24 regions in Korea from 1988 - 2017, calculated from average monthly meteorological factors, is displayed. Because of the recent increase on the average temperature due to the global warming, the average of EADD is calculated to be 265 days, which showed 5 days increased compared to the data from 30 years ago shown on Table 1; the maximum 
Yeonjung HAN $\cdot$ Chang-Deuk EOM $\cdot$ Sang-Min LEE $\cdot$ Yonggun PARK

Table 1. Air drying calendars of 24 regions in Korea (Jung and Park, 1986)

\begin{tabular}{|c|c|c|c|c|c|c|c|c|c|c|c|c|c|}
\hline Districts & Jan & Feb & Mar & Apr & May & Jun & Jul & Aug & Sep & Oct & Nov & Dec & $\begin{array}{c}\text { Sum } \\
\text { (days) }\end{array}$ \\
\hline Sokcho $^{6}$ & $12 \pm 3$ & $13 \pm 3$ & $17 \pm 3$ & $22 \pm 3$ & $26 \pm 3$ & $30 \pm 0$ & $30 \pm 0$ & $30 \pm 0$ & $28 \pm 1$ & $25 \pm 2$ & $20 \pm 1$ & $15 \pm 1$ & $268 \pm 10$ \\
\hline Chuncheon $^{4}$ & $6 \pm 3$ & $9 \pm 3$ & $14 \pm 2$ & $20 \pm 1$ & $26 \pm 2$ & $30 \pm 0$ & $30 \pm 0$ & $30 \pm 0$ & $27 \pm 3$ & $21 \pm 3$ & $15 \pm 3$ & $9 \pm 2$ & $237 \pm 7$ \\
\hline Gangneung ${ }^{1}$ & $11 \pm 2$ & $12 \pm 3$ & $16 \pm 2$ & $22 \pm 3$ & $27 \pm 3$ & $30 \pm 0$ & $30 \pm 0$ & $30 \pm 0$ & $28 \pm 1$ & $24 \pm 1$ & $20 \pm 1$ & $14 \pm 2$ & $265 \pm 7$ \\
\hline Seoul $^{1}$ & $8 \pm 3$ & $10 \pm 2$ & $15 \pm 2$ & $21 \pm 2$ & $26 \pm 2$ & $30 \pm 0$ & $30 \pm 0$ & $30 \pm 0$ & $29 \pm 1$ & $25 \pm 2$ & $16 \pm 2$ & $10 \pm 2$ & $248 \pm 6$ \\
\hline Incheon $^{1}$ & $9 \pm 3$ & $11 \pm 2$ & $15 \pm 0$ & $20 \pm 1$ & $25 \pm 1$ & $30 \pm 0$ & $30 \pm 0$ & $30 \pm 0$ & $29 \pm 1$ & $25 \pm 0$ & $19 \pm 2$ & $12 \pm 3$ & $254 \pm 5$ \\
\hline Ulleung-do ${ }^{1}$ & $14 \pm 2$ & $14 \pm 2$ & $17 \pm 3$ & $22 \pm 3$ & $26 \pm 3$ & $30 \pm 0$ & $30 \pm 0$ & $30 \pm 0$ & $29 \pm 1$ & $26 \pm 2$ & $21 \pm 2$ & $16 \pm 2$ & $275 \pm 9$ \\
\hline Suwon $^{3}$ & $8 \pm 3$ & $9 \pm 2$ & $15 \pm 2$ & $20 \pm 1$ & $25 \pm 1$ & $30 \pm 0$ & $30 \pm 0$ & $30 \pm 0$ & $29 \pm 1$ & $22 \pm 3$ & $16 \pm 2$ & $10 \pm 2$ & $244 \pm 7$ \\
\hline Seosan $^{6}$ & $9 \pm 2$ & $10 \pm 1$ & $15 \pm 1$ & $20 \pm 0$ & $25 \pm 0$ & $30 \pm 0$ & $30 \pm 0$ & $30 \pm 0$ & $29 \pm 1$ & $24 \pm 2$ & $18 \pm 3$ & $11 \pm 2$ & $252 \pm 6$ \\
\hline Cheongju $^{5}$ & $8 \pm 3$ & $10 \pm 2$ & $14 \pm 2$ & $20 \pm 0$ & $25 \pm 0$ & $30 \pm 0$ & $30 \pm 0$ & $30 \pm 0$ & $28 \pm 2$ & $22 \pm 3$ & $15 \pm 2$ & $10 \pm 2$ & $241 \pm 9$ \\
\hline Daejeon $^{7}$ & $9 \pm 2$ & $10 \pm 2$ & $15 \pm 1$ & $20 \pm 1$ & $25 \pm 1$ & $30 \pm 0$ & $30 \pm 0$ & $30 \pm 0$ & $29 \pm 1$ & $23 \pm 2$ & $16 \pm 2$ & $10 \pm 1$ & $246 \pm 8$ \\
\hline Chupungnyeong ${ }^{1}$ & $9 \pm 2$ & $11 \pm 2$ & $15 \pm 1$ & $21 \pm 2$ & $26 \pm 2$ & $30 \pm 0$ & $30 \pm 0$ & $30 \pm 0$ & $28 \pm 1$ & $23 \pm 3$ & $17 \pm 2$ & $12 \pm 3$ & $251 \pm 8$ \\
\hline Pohang $^{1}$ & $11 \pm 2$ & $13 \pm 2$ & $18 \pm 3$ & $22 \pm 3$ & $26 \pm 2$ & $30 \pm 0$ & $30 \pm 0$ & $30 \pm 0$ & $28 \pm 1$ & $24 \pm 1$ & $20 \pm 1$ & $14 \pm 2$ & $267 \pm 9$ \\
\hline Gunsan $^{6}$ & $10 \pm 3$ & $11 \pm 2$ & $15 \pm 0$ & $20 \pm 2$ & $25 \pm 0$ & $30 \pm 0$ & $30 \pm 0$ & $30 \pm 0$ & $30 \pm 1$ & $25 \pm 0$ & $19 \pm 2$ & $13 \pm 3$ & $256 \pm 5$ \\
\hline Daegu $^{1}$ & $9 \pm 2$ & $11 \pm 2$ & $15 \pm 1$ & $21 \pm 2$ & $26 \pm 2$ & $30 \pm 0$ & $30 \pm 0$ & $30 \pm 0$ & $28 \pm 1$ & $23 \pm 3$ & $17 \pm 3$ & $11 \pm 3$ & $252 \pm 8$ \\
\hline Jeonju $^{1}$ & $9 \pm 3$ & $10 \pm 2$ & $15 \pm 1$ & $20 \pm 1$ & $25 \pm 1$ & $30 \pm 0$ & $30 \pm 0$ & $30 \pm 0$ & $29 \pm 1$ & $23 \pm 2$ & $16 \pm 3$ & $11 \pm 2$ & $250 \pm 5$ \\
\hline Ulsan $^{1}$ & $12 \pm 2$ & $14 \pm 2$ & $18 \pm 3$ & $21 \pm 3$ & $25 \pm 2$ & $30 \pm 0$ & $30 \pm 0$ & $30 \pm 0$ & $28 \pm 1$ & $24 \pm 1$ & $20 \pm 1$ & $14 \pm 2$ & $266 \pm 8$ \\
\hline Gwangju $^{1}$ & $10 \pm 2$ & $11 \pm 2$ & $15 \pm 1$ & $21 \pm 2$ & $25 \pm 1$ & $30 \pm 0$ & $30 \pm 0$ & $30 \pm 0$ & $29 \pm 1$ & $25 \pm 1$ & $18 \pm 2$ & $13 \pm 3$ & $257 \pm 7$ \\
\hline Busan $^{1}$ & $14 \pm 2$ & $15 \pm 2$ & $19 \pm 2$ & $23 \pm 3$ & $25 \pm 2$ & $30 \pm 0$ & $30 \pm 0$ & $30 \pm 0$ & $28 \pm 1$ & $26 \pm 2$ & $20 \pm 3$ & $16 \pm 3$ & $277 \pm 9$ \\
\hline Tongyeong $^{6}$ & $14 \pm 2$ & $15 \pm 2$ & $18 \pm 3$ & $24 \pm 3$ & $26 \pm 2$ & $30 \pm 0$ & $30 \pm 0$ & $30 \pm 0$ & $28 \pm 1$ & $25 \pm 2$ & $20 \pm 1$ & $15 \pm 2$ & $276 \pm 8$ \\
\hline Mokpo $^{1}$ & $11 \pm 2$ & $13 \pm 3$ & $16 \pm 2$ & $20 \pm 2$ & $25 \pm 1$ & $30 \pm 0$ & $30 \pm 0$ & $30 \pm 0$ & $29 \pm 1$ & $25 \pm 1$ & $20 \pm 0$ & $15 \pm 2$ & $264 \pm 6$ \\
\hline Yeosu $^{1}$ & $12 \pm 3$ & $14 \pm 2$ & $18 \pm 3$ & $22 \pm 3$ & $25 \pm 2$ & $30 \pm 0$ & $30 \pm 0$ & $30 \pm 0$ & $29 \pm 1$ & $25 \pm 1$ & $20 \pm 1$ & $15 \pm 2$ & $271 \pm 9$ \\
\hline $\mathrm{Jeju}^{1}$ & $15 \pm 1$ & $15 \pm 1$ & $19 \pm 2$ & $22 \pm 3$ & $25 \pm 2$ & $30 \pm 0$ & $30 \pm 0$ & $30 \pm 0$ & $29 \pm 1$ & $25 \pm 1$ & $21 \pm 2$ & $17 \pm 3$ & $278 \pm 7$ \\
\hline Seogwipo $^{2}$ & $16 \pm 2$ & $17 \pm 2$ & $20 \pm 1$ & $24 \pm 2$ & $25 \pm 2$ & $30 \pm 0$ & $30 \pm 0$ & $30 \pm 0$ & $29 \pm 1$ & $27 \pm 2$ & $23 \pm 3$ & $18 \pm 3$ & $288 \pm 2$ \\
\hline Jinju $^{8}$ & $10 \pm 1$ & $12 \pm 3$ & $16 \pm 2$ & $21 \pm 2$ & $26 \pm 2$ & $30 \pm 0$ & $30 \pm 0$ & $30 \pm 0$ & $29 \pm 1$ & $24 \pm 2$ & $18 \pm 3$ & $12 \pm 2$ & $259 \pm 2$ \\
\hline
\end{tabular}

${ }^{1} 1955-1984,{ }^{2} 1962-1982,{ }^{3} 1964-1984,{ }^{4} 1966-1984,{ }^{5} 1967-1984,{ }^{6} 1968-1984,{ }^{7} 1969-1984,{ }^{8} 1970-1984$.

EADD was 291 days (Seogwipo), the minimum was 239 days (Chuncheon). By region, EADD of Daegu was increased by 10 days, from 252 to 262, EADD of Jinju was also increased by 1 day, from 259 to 260 . The regions showed more than 6 days increase in EADD are Suwon (6 days), Cheongju (8 days), Daejeon ( 8 days), Chupungnyeong (7 days), Pohang (6 days), Daegu (10 days), Jeonju (6 days), and Ulsan (6 days). The factors affecting EADD are in the order of temper- ature, relative humidity, and wind speed, and the deduction of EADD due to the wind speed was occurred once in each Chupungnyeong on June 2001 and Ulleung-do on June 2013. The difference among monthly EADD can explain the seasonal change in air drying speed, and by utilizing each region's air drying calendar, it is possible to predict the days require to air drying woods (McMillen, 1978; Jung and Park, 1986). 
Moisture Content Change of Korean Red Pine Logs During Air Drying: I. Effective Air Drying Days in Major Regions in Korea

Table 2. Air drying calendars of 24 regions in Korea (1988 - 2017)

\begin{tabular}{|c|c|c|c|c|c|c|c|c|c|c|c|c|c|}
\hline Districts & Jan & Feb & Mar & Apr & May & Jun & Jul & Aug & Sep & Oct & Nov & Dec & $\begin{array}{c}\text { Sum } \\
\text { (days) }\end{array}$ \\
\hline Sokcho & $12 \pm 2$ & $13 \pm 2$ & $18 \pm 3$ & $23 \pm 3$ & $26 \pm 3$ & $30 \pm 0$ & $30 \pm 0$ & $30 \pm 0$ & $28 \pm 0$ & $25 \pm 2$ & $20 \pm 1$ & $1414 \pm 2$ & $271 \pm 10$ \\
\hline Chuncheon & $7 \pm 3$ & $10 \pm 2$ & $15 \pm 0$ & $21 \pm 2$ & $26 \pm 2$ & $30 \pm 0$ & $30 \pm 0$ & $30 \pm 0$ & $28 \pm 4$ & $21 \pm 3$ & $15 \pm 2$ & $7 \pm 3$ & $239 \pm 10$ \\
\hline Gangneung & $12 \pm 3$ & $13 \pm 3$ & $17 \pm 3$ & $24 \pm 2$ & $27 \pm 3$ & $30 \pm 0$ & $30 \pm 0$ & $30 \pm 0$ & $28 \pm 3$ & $25 \pm 3$ & $20 \pm 2$ & $12 \pm 3$ & $268 \pm 12$ \\
\hline Seoul & $9 \pm 2$ & $11 \pm 3$ & $15 \pm 2$ & $21 \pm 2$ & $26 \pm 2$ & $30 \pm 0$ & $30 \pm 0$ & $30 \pm 0$ & $29 \pm 1$ & $24 \pm 2$ & $17 \pm 2$ & $10 \pm 2$ & $252 \pm 9$ \\
\hline Incheon & $10 \pm 2$ & $12 \pm 3$ & $16 \pm 2$ & $21 \pm 2$ & $25 \pm 1$ & $30 \pm 0$ & $30 \pm 0$ & $30 \pm 0$ & $29 \pm 1$ & $25 \pm 1$ & $18 \pm 2$ & $12 \pm 3$ & $257 \pm 9$ \\
\hline Ulleung-do & $14 \pm 2$ & $15 \pm 2$ & $18 \pm 2$ & $23 \pm 3$ & $27 \pm 2$ & $30 \pm 0$ & $30 \pm 0$ & $30 \pm 0$ & $29 \pm 1$ & $26 \pm 2$ & $21 \pm 2$ & $17 \pm 3$ & $279 \pm 11$ \\
\hline Suwon & $9 \pm 2$ & $11 \pm 2$ & $15 \pm 1$ & $21 \pm 2$ & $25 \pm 1$ & $30 \pm 0$ & $30 \pm 0$ & $30 \pm 0$ & $29 \pm 1$ & $24 \pm 2$ & $16 \pm 2$ & $10 \pm 2$ & $250 \pm 7$ \\
\hline Seosan & $10 \pm 1$ & $11 \pm 2$ & $15 \pm 1$ & $21 \pm 2$ & $25 \pm 1$ & $30 \pm 0$ & $30 \pm 0$ & $30 \pm 0$ & $29 \pm 1$ & $25 \pm 1$ & $17 \pm 2$ & $12 \pm 2$ & $255 \pm 8$ \\
\hline Cheongju & $8 \pm 2$ & $11 \pm 2$ & $15 \pm 2$ & $22 \pm 2$ & $26 \pm 2$ & $30 \pm 0$ & $30 \pm 0$ & $30 \pm 0$ & $29 \pm 1$ & $23 \pm 3$ & $16 \pm 2$ & $9 \pm 2$ & $249 \pm 10$ \\
\hline Daejeon & $10 \pm 2$ & $12 \pm 2$ & $16 \pm 2$ & $22 \pm 2$ & $26 \pm 2$ & $30 \pm 0$ & $30 \pm 0$ & $30 \pm 0$ & $28 \pm 1$ & $23 \pm 2$ & $17 \pm 2$ & $11 \pm 3$ & $254 \pm 8$ \\
\hline Chupungnyeong & $10 \pm 2$ & $12 \pm 2$ & $16 \pm 2$ & $23 \pm 2$ & $26 \pm 2$ & $30 \pm 0$ & $30 \pm 0$ & $30 \pm 0$ & $28 \pm 1$ & $24 \pm 2$ & $17 \pm 2$ & $12 \pm 2$ & $258 \pm 11$ \\
\hline Pohang & $13 \pm 3$ & $14 \pm 2$ & $18 \pm 3$ & $24 \pm 2$ & $27 \pm 3$ & $30 \pm 0$ & $30 \pm 0$ & $30 \pm 0$ & $28 \pm 0$ & $25 \pm 1$ & $20 \pm 1$ & $14 \pm 2$ & $273 \pm 11$ \\
\hline Gunsan & $10 \pm 2$ & $12 \pm 2$ & $15 \pm 1$ & $20 \pm 1$ & $25 \pm 1$ & $30 \pm 0$ & $30 \pm 0$ & $30 \pm 0$ & $29 \pm 4$ & $25 \pm 3$ & $19 \pm 3$ & $13 \pm 2$ & $259 \pm 7$ \\
\hline Daegu & $10 \pm 2$ & $12 \pm 3$ & $17 \pm 1$ & $23 \pm 2$ & $27 \pm 2$ & $30 \pm 0$ & $30 \pm 0$ & $30 \pm 0$ & $28 \pm 1$ & $24 \pm 1$ & $18 \pm 2$ & $13 \pm 3$ & $262 \pm 11$ \\
\hline Jeonju & $10 \pm 2$ & $12 \pm 2$ & $15 \pm 2$ & $21 \pm 2$ & $26 \pm 2$ & $30 \pm 0$ & $30 \pm 0$ & $30 \pm 0$ & $29 \pm 1$ & $24 \pm 1$ & $17 \pm 3$ & $12 \pm 3$ & $256 \pm 10$ \\
\hline Ulsan & $13 \pm 3$ & $14 \pm 2$ & $18 \pm 2$ & $23 \pm 2$ & $26 \pm 2$ & $30 \pm 0$ & $30 \pm 0$ & $30 \pm 0$ & $28 \pm 1$ & $24 \pm 1$ & $20 \pm 1$ & $15 \pm 2$ & $272 \pm 8$ \\
\hline Gwangju & $10 \pm 2$ & $12 \pm 3$ & $16 \pm 2$ & $22 \pm 2$ & $26 \pm 2$ & $30 \pm 0$ & $30 \pm 0$ & $30 \pm 0$ & $29 \pm 1$ & $25 \pm 1$ & $18 \pm 2$ & $13 \pm 3$ & $262 \pm 10$ \\
\hline Busan & $14 \pm 2$ & $16 \pm 2$ & $19 \pm 2$ & $24 \pm 2$ & $25 \pm 3$ & $30 \pm 0$ & $30 \pm 0$ & $30 \pm 0$ & $28 \pm 1$ & $26 \pm 2$ & $21 \pm 2$ & $16 \pm 2$ & $280 \pm 10$ \\
\hline Tongyeong & $14 \pm 2$ & $15 \pm 1$ & $20 \pm 1$ & $24 \pm 2$ & $25 \pm 2$ & $30 \pm 0$ & $30 \pm 0$ & $30 \pm 0$ & $29 \pm 1$ & $25 \pm 2$ & $21 \pm 2$ & $16 \pm 2$ & $278 \pm 7$ \\
\hline Mokpo & $12 \pm 3$ & $13 \pm 2$ & $17 \pm 2$ & $21 \pm 2$ & $25 \pm 1$ & $30 \pm 0$ & $30 \pm 0$ & $30 \pm 0$ & $29 \pm 1$ & $25 \pm 0$ & $20 \pm 0$ & $14 \pm 2$ & $268 \pm 8$ \\
\hline Yeosu & $13 \pm 3$ & $15 \pm 1$ & $19 \pm 2$ & $23 \pm 3$ & $26 \pm 3$ & $30 \pm 0$ & $30 \pm 0$ & $30 \pm 0$ & $29 \pm 1$ & $26 \pm 2$ & $21 \pm 2$ & $15 \pm 2$ & $276 \pm 10$ \\
\hline Jeju & $15 \pm 2$ & $16 \pm 2$ & $19 \pm 2$ & $23 \pm 2$ & $25 \pm 2$ & $30 \pm 0$ & $30 \pm 0$ & $30 \pm 0$ & $29 \pm 1$ & $26 \pm 2$ & $21 \pm 2$ & $17 \pm 3$ & $281 \pm 9$ \\
\hline Seogwipo & $16 \pm 2$ & $17 \pm 3$ & $20 \pm 1$ & $24 \pm 2$ & $26 \pm 2$ & $30 \pm 0$ & $30 \pm 0$ & $30 \pm 0$ & $29 \pm 1$ & $28 \pm 2$ & $23 \pm 3$ & $19 \pm 2$ & $291 \pm 10$ \\
\hline Jinju & $10 \pm 1$ & $13 \pm 3$ & $17 \pm 2$ & $22 \pm 2$ & $26 \pm 2$ & $30 \pm 0$ & $30 \pm 0$ & $30 \pm 0$ & $28 \pm 1$ & $24 \pm 1$ & $17 \pm 2$ & $12 \pm 3$ & $260 \pm 12$ \\
\hline
\end{tabular}

\subsection{Changes in regional EADD zones}

Table 3 shows the categorized regions in Korea based on the four EADD zones using the 30 years of meteorological data from 1988 to 2017. Basis on the data from 1986, comparing the EADD zones from 1955 to 1984 , Seoul, Suwon, Daejeon changed their zone from the $1^{\text {st }}$ zone to the $2^{\text {nd }}$ zone. Daegu, Gwangju, Jinju which previously categorized as the $2^{\text {nd }}$ zone, shifted their zone to $3^{\text {rd }}$ zone, and Sokcho, Pohang, Ulsan shifted their zone from the $3^{\text {rd }}$ to $4^{\text {th }}$. As we previously observed from the average EADD increased by 5 days, EADD zones were also shifted northward in latitude, which seemed to be affected by the recent increase of average temperature due to the global warming. Unlike Korea's usual climate classification which is distinguished by the temperature and precipitation, EADD zones is distinguished by temperature and relative humidity. Therefore, south and east coastal region were categorized under the $4^{\text {th }}$ zone, the south province and Gangneung were categorized under the $3^{\text {rd }}$ zone, and the inland area was categorized in $2^{\text {nd }}$ and $1^{\text {st }}$ zone. 
Yeonjung HAN $\cdot$ Chang-Deuk EOM $\cdot$ Sang-Min LEE $\cdot$ Yonggun PARK

Table 3. Four zones of effective air drying days in Korea

\begin{tabular}{cll}
\hline & Range of EADD & \multicolumn{1}{c}{ Districts } \\
\hline \hline 1st zone & Below 250 days & Chuncheon, Cheongju \\
2nd zone & $250-259$ days & Seoul, Incheon, Suwon, Seosan, Daejeon, Chupungnyeong, Gunsan, Jeonju \\
3rd zone & $260-269$ days & Gangneung, Daegu, Gwangju, Mokpo, Jinju \\
4th zone & Above 270 days & Sokcho, Ulleung-do, Pohang, Ulsan, Busan, Tongyeong, Yeosu, Jeju, Seogwipo \\
\hline
\end{tabular}

Table 4. Monthly average temperature, relative humidity, wind speed, and equilibrium moisture content of Seoul

\begin{tabular}{|c|c|c|c|c|c|c|c|c|c|c|c|c|}
\hline 2016 & Jan & Feb & Mar & Apr & May & Jun & Jul & Aug & Sep & Oct & Nov & Dec \\
\hline Temp. $\left({ }^{\circ} \mathrm{C}\right)$ & -3.2 & 0.2 & 7.0 & 14.1 & 19.6 & 23.6 & 26.2 & 28.0 & 23.1 & 16.1 & 6.8 & 1.2 \\
\hline RH (\%) & 53 & 52 & 51 & 55 & 56 & 63 & 73 & 64 & 65 & 62 & 57 & 59 \\
\hline Wind speed $(\mathrm{m} / \mathrm{s})$ & 2.5 & 2.8 & 2.4 & 2.4 & 2.4 & 2.1 & 2.1 & 2.1 & 2.0 & 2.1 & 2.2 & 2.2 \\
\hline EMC (\%) & 9.9 & 9.8 & 9.6 & 10.2 & 10.3 & 11.5 & 13.8 & 11.5 & 12.0 & 11.6 & 10.7 & 11.1 \\
\hline 2017 & Jan & Feb & Mar & Apr & May & Jun & Jul & Aug & Sep & Oct & Nov & Dec \\
\hline Temp. $\left({ }^{\circ} \mathrm{C}\right)$ & -1.8 & -0.2 & 6.3 & 13.9 & 19.5 & 23.3 & 26.9 & 25.9 & 22.1 & 16.4 & 5.6 & -1.9 \\
\hline RH (\%) & 55 & 54 & 48 & 52 & 52 & 57 & 77 & 71 & 61 & 56 & 54 & 56 \\
\hline Wind speed $(\mathrm{m} / \mathrm{s})$ & 2.3 & 2.4 & 2.4 & 2.6 & 2.4 & 2.4 & 2.0 & 2.3 & 2.0 & 1.9 & 2.1 & 1.8 \\
\hline EMC (\%) & 10.3 & 10.1 & 9.1 & 9.7 & 9.6 & 10.3 & 14.9 & 13.3 & 11.2 & 10.4 & 10.2 & 10.5 \\
\hline 2018 & Jan & Feb & Mar & Apr & May & Jun & Jul & Aug & Sep & Oct & & \\
\hline Temp. $\left({ }^{\circ} \mathrm{C}\right)$ & -4.0 & -1.6 & 8.1 & 13.0 & 18.2 & 23.1 & 27.8 & 28.8 & 21.5 & 13.1 & & \\
\hline RH (\%) & 48 & 45 & 59 & 55 & 63 & 63 & 68 & 65 & 61 & 59 & & \\
\hline Wind speed $(\mathrm{m} / \mathrm{s})$ & 1.9 & 2.2 & 1.9 & 2.0 & 1.7 & 1.7 & 1.5 & 1.7 & 1.6 & 1.5 & & \\
\hline EMC (\%) & 9.0 & 8.6 & 11.1 & 10.3 & 11.7 & 11.5 & 12.4 & 11.7 & 11.2 & 11.0 & & \\
\hline
\end{tabular}

\subsection{Changes in equilibrium moisture content and the climate in Seoul}

Meteorologically speaking, although dividing one calendar year to four seasons, three months in each season, is reflected upon the solar zenith angle and the length of day and night which brings the universality based on the latitude, another meteorological method of defining four zones is defined based on the average daily temperature as following (Kwon et al., 2007): I) The cold period has an average daily temperature of below $0^{\circ} \mathrm{C}$ and abundant of snow; II) The cool period has an average daily temperature range from $0-10^{\circ} \mathrm{C}$, and frost is observed occasionally; III) The warm period has an average daily temperature range from $10-20^{\circ} \mathrm{C}$, and there is no frost observed; IV) The hot period has the average daily temperature above $21^{\circ} \mathrm{C}$. Korea has a repetitive II-III-IV-I climate condition, total of four seasonal changes are observed in a calendar year.

In order to examine the changes in EADD and equilibrium MC, Seoul region's monthly average temperature, relative humidity, wind speed and each corresponding equilibrium MC are stated in Table 4.

Based on recent 3 years of average monthly temperature in Seoul, January and February are categorized as (I), March and December are in category (II), April, May, October, November are in category (III), and June, July, August, September are in category (IV). Equlibrium MC was affected more by relative humidity than the temperature, and it had a tendency of decreasing 
less than $10 \%$ during the winter but gradually increased to have equilibrium $\mathrm{MC}$ of $12.4 \%$ to $14.9 \%$ during summer.

Seoul region's meteorological factors including average monthly temperature, relative humidity, and wind speed stated in this study will be used as a basic data to predict changes in MC distribution of Korean red pine logs during air drying. Decrease in $\mathrm{MC}$ in the process of air drying will be considered as a dependent variable, initial MC and diameter of the logs, temperature, relative humidity and wind speed will be used as independent variables when they are applied to a multiple regression analysis. Moreover, the data will be used to determine 2-dimensional mass transfer coefficients, moisture diffusion coefficient and surface emission coefficient, in order to to predict the MC distribution of Korean red pine logs.

\section{CONCLUSION}

In order to establish a pilot study for analyzing MC level for Korean red pine logs during air drying, the study provides the calculated EADD using the meteorological data from 24 regions in Korea such as average monthly temperature, relative humidity, wind speed, and based on the result, categorizes the EADD zone. The obtained conclusions are followings:

1. The average EADD was calculated to be 265 days with a range of 239 - 291 days, based on the 30 -years of average monthly meteorological data from 1988 to 2017 in 24 regions in Korea. This result showed a total of 5 days increase, compared to 260 days which is the average of the study in 1986. The meteorological factors affecting EADD were in the order of temperature, relative humidity, and wind speed, and EADD deduction resulted from the relative humidity and wind speed was minimal.

2. As a result of dividing Korea into 4 zones of
EADD, the zones of EADD were shifted northward compared to previous study due to global warming.

3. The difference in monthly EADD can be used to explain the change in seasonal air drying speed, and if utilized with air drying calendar of each region, it is expected to predict the air drying days for woods.

\section{REFERENCES}

Denig, J., Wengert, E. 1982. Estimating air-drying moisture content loss for red oak and yellow-poplar lumber. Forest Products Journal 32(2): 26-31.

Jung, H.S. 1985. Study on air-drying characteristics of Taun lumber and air-drying calendar (I). Journal of the Korean Wood Science and Technology 13(3): 27-33.

Jung, H.S., Park, M.J. 1986. Air-drying calendar of 24 districts in Korea. Journal of the Korean Wood Science and Technology 14(3): 16-22.

Jung, H.S., Han, G.S., Lee, N.H. 1986. Estimating moisture content losses of air-drying related to meteorological variables for Korean red pine and pitch pine. Journal of the Korean Wood Science and Technology 14(6): 7-13.

Jung, H.-S., Kang, H.-Y., Park, J.-H., Lee, N.-H., Lee, H.-W., Kang, C.-W., Yeo, H. 2005. New Wood Drying. SNU Press, pp. 481.

Korea Meteorological Administration. http://data.kma. go.kr

Kwon, Y.-A., Kwon, W.-T., Boo, K.-O. 2007. Future projections on the change of onset date and duration of natural seasons using SRES A1B data in South Korea. Journal of the Korean Geographical Society 42(6): 835-850.

McMillen, J.M., Wengert, E.M. 1978. Drying eastern hardwood lumber. Agric. Handb. 528. Washington, DC: U.S. Department of Agriculture, Forest Service, pp. 104. 
Peck, E.C. 1954. Effects of machine stacking on drying rate and degrade. Southern Lumberman 189: 62-67.

Peck, E.C., Kotok, E.S., Mueller, L.A. 1956. Air drying of ponderosa pine in Arizona. Forest Products Journal 6(2): 88-96.

Peck, E.C. 1957. Air drying and sticker staining of 4/4 sugar maple flooring stock in Upper Michigan. Rep. 2068. Madison, WI: U.S. Department of Agriculture, Forest Service, Forest Products Laboratory.

Peck, E.C. 1959. Air drying 4/4 red oak in southern Wisconsin. Forest Products Journal 9(7): 236-242. Ra, J.B. 2018. Determination of moisture index in Korea. Journal of the Korean Wood Science and
Technology 46(4): 301-308.

Rietz, R.C. 1972. A calendar for air drying lumber in the upper Midwest. Res. Note FPL-0224. Madison, WI: U.S. Department of Agriculture, Forest Service, Forest Products Laboratory.

Simpson, W.T. 1973. Predicting equilibrium moisture content of wood by mathematical models. Wood and Fiber 5(1): 41-49.

Simpson, W.T., Hart, C.A. 2001. Method for estimating air-drying times of lumber. Forest Products Journal 51(11/12): 56-63.

U.S. Department of Agriculture. 1975. Growing degree days. Weekly Weather and Crop Bulletin 62(15): 10-12. 


\title{
APPENDIX
}

\author{
(Korean Version)
}

\section{소나무 원목의 천연건조 중 함수율 변화: I. 국내 주요지역의 유효천연건조일수 조사}

초록 : 천연건조는 건조되는 목재의 수종, 밀도와 크기, 천연건조장의 위치조건과 함께 건조지역의 기상인자를 고려해야 한다. 우리나라와 같이 4계절의 구분이 있는 지역은 여름과 겨울의 온도 및 상대습도의 차이가 크기 때문에 기상인자에 대한 연구가 필요하다. 본 연구에서는 소나무 원목의 천연건조 중 함수율 변화를 분석하기 위한 기초자료로 국내 24 지역의 1988년부 터 2017년까지 30년간 월별 평균 기온, 상대습도, 풍속의 기상인자를 이용하여 유효천연건조일수를 산출하였다. 24지역의 유효천연건조일수는 239 - 291일 범위로 평균값은 265일이었다. 이 결과는 1955년부터 1984년까지의 기상인자로 산출된 유효천연건조일수의 평균인 260 일 비하여 약 5 일 증가한 값이다. 유효천연건조일수와 기상인자들의 다중회귀분석 결과, 유효천 연건조일수에 영향을 미치는 기상인자는 온도, 상대습도, 풍속의 순서였다. 지역별로 산출된 유효천연건조일수를 이용하여 우리나라를 4개의 유효천연건조일수대로 구분한 결과, 유효천연건조일수대가 지구온난화의 영향으로 선행연구에서 제시된 것에 비하여 위도상 북쪽으로 상승하였다. 서울지역에서 수행된 소나무 원목의 천연건조 중 함수율 분포를 예측하기 위한 기초자료로 2016년부터 2018년까지 3년간의 월별 평균온도, 상대습도, 풍속의 기상인자를 제시하고, 그에 따른 평형함수율 변화를 조사하였다.

\section{1. 서 론}

천연건조(air drying; natural drying)는 생재상태의 목재를 천연건조장에 쌓아 자연의 대기조건에서 폭로시켜 말리는 것을 의미한다(Jung et al., 2005). 천연건조는 인공건조에 비하여 초기 설비 및 에너지 비용이 거의 없는 장점이 있는 반면에, 기후와 입지조건의 영향을 크게 받으며 넓은 장소가 필요하고, 기건함수율 이하로 건조할 수 없다는 단점이 있다. 천연건조는 목재의 수종, 밀도와 크기, 천연건조장의 위치조건과 함께 기상인자를 고려해야 되기 때문에 다양한 함수율을 갖는 원목과 제재목의 천연건조에 소요되는 시간을 예측하는 것은 쉽지 않다. 우리나라와 같이 4계절의 구분이 있는 지역에서는 여름과 겨울의 온도차 이에 의해 어느 계절에 천연건조를 시작하느냐에 따라 건조소요시간의 차이가 있다(Simpson and Hart, 2001).

유효천연건조일수(effective air drying days; EADD)는 기상조건에 따른 1개월 중 천연건조에 적당한 일수(Rietz, 1972)로 이를 이용하면 천연건조 캘린더(air drying calendar)를 지역별로 제시할 수 있다. 천연건조 및 유효천연건조일수와 관련된 국내·외 연구는 두께 $50 \mathrm{~mm}$ 이하인 침엽수와 활엽수에 대하여 수행되었다. 국내에는 남양재 중 타운(taun) 제재목이 함수율 $20 \%$ 에 도달하는데 소요되는 천연건조 일수를 분석하고 천연건조 캘린더를 작성한 연구(Jung, 1985), 국내 24지역의 유효천연건 조일수를 산출하고 이를 바탕으로 4개 권역으로 분류한 연구(Jung and Park, 1986), 기후구분을 위해 고안된 수분지수(moisture index)를 국내 82지역의 기상자료를 이용하여 산출하고 지역별로 비교한 연구(Ra, 2018)와 국내 기상자료를 활용하여 소나무와 리기다소나무의 천연건조 중 함수율 변화를 회귀식으로 제시한 연구(Jung et al., 1986) 등이 있다. 미국에는 두께 $25 \mathrm{~mm}$ - $50 \mathrm{~mm}$ 범위인 너도밤나무(American beech; Peck, 1954), 폰데로사파인(ponderosa pine; Peck et al., 1956), 사탕단풍나무 (sugar maple; Peck, 1957), 적참나무(northern red oak; Peck, 1959), 더글라스퍼(Douglas fir), 백합나무(yellow poplar; Denig and Wengert, 1982) 등의 수종에 대하여 제재목의 두께, 잔적시기, 천연건조장의 위치, 기상조건에 따른 건조소요시간의 측정 연구 등이 있다. 또한 미국 농림부(USDA, 1975)가 제시한 '생장온도일수'(growing degree days)의 평균값에 의거하여 미국을 지역별로 구분하고, 각 지역별 천연건조 소요시간을 측정한 연구가 수행되었다(Rietz, 1972; McMillen and Wengert, 1978).

본 연구는 국산 소나무 원목의 천연건조 중 함수율 변화를 분석하기 위한 선행연구로 기상청 국가기후데이터센터(Korea Meteorological Administration; http://data.kma.go.kr)에 제시된 24지역에 대한 30년간 기온, 상대습도, 풍속 등 기상자료를 활용하여 각 지역별 유효천연건조일수를 산출하였다. 그 결과를 1986년에 각 지역별로 산출된 결과(Jung and Park, 1986)와 비교하여 기후변화에 따른 유효천연건조일수의 변화를 분석하였다. 


\section{2. 재료 및 방법}

\section{1. 국내 24지역 기상자료 수집}

천연건조 중 목재의 함수율 감소에 영향을 미치는 온도, 상대습도, 풍속 등의 기상인자를 수집하기 위하여 기상청 국가기후데 이터센터를 이용하였다. 국가기후데이터센터에는 국내 주요지역의 기온, 강수량, 풍속, 풍향, 습도, 일사량 등의 기후요소에 대한 통계자료가 제시되어 있다. 본 연구에서는 1986년에 산출된 유효천연건조일수(Jung and Park, 1986)와 최근 30년간 국내 주요지역의 유효천연건조일수 변화를 비교하기 위하여 선행연구와 동일한 속초, 춘천, 강릉, 서울, 인천, 울릉도, 수원, 서산, 청주, 대전, 추풍령, 포항, 군산, 대구, 전주, 울산, 광주, 부산, 통영, 목포, 여수, 제주, 서귀포, 진주 등 24지역에 대한 월평균 기온, 상대습도, 풍속의 통계자료를 수집하였다.

\section{2. 유효천연건조일수 산출 방법}

기상청 국가기후데이터센터의 기상자료에 근거하여 유효천연건조일수를 산출하였다. 유효천연건조일수의 산출은 미국 임산 물연구소(USDA Forest Service Forest Products Laboratory; Reitz, 1972)에서 제시한 방법을 이용하였다. 천연건조에 적당한 1 달의 유효천연건조일수를 30 일로 가정하고, 여름철 $(6,7,8$ 월)에 속하는 달의 평균 상대습도가 연평균 상대습도에 비하여 $5 \%$ 이상 높고, 평균 풍속이 연평균 풍속에 비하여 $1.8 \mathrm{~m} / \mathrm{s}$ 이상 적을 때 2 일을 공제하였다. 봄철 $(3,4,5$ 월), 가을철 $(9,10$, 11 월), 겨울철( $12,1,2$ 월)에 속하는 달의 평균 기온이 여름철의 3 개월의 평균 기온보다 $5.5^{\circ} \mathrm{C}$ 가 적을 때마다 5 일을 공제하고, 평균 상대습도가 연평균 상대습도에 비하여 $5 \%$ 이상 높거나 평균 풍속이 연평균 풍속에 비하여 $1.8 \mathrm{~m} / \mathrm{s}$ 이상 적을 때 2 일을 공제하였다. 상대습도와 풍속의 2가지 조건이 동시에 성립하는 경우 4일을 공제하였다(Jung and Park, 1986).

\section{3. 지역별 유효천연건조일수대 구분}

우리나라의 유효천연건조일수대는 유효천연건조일수에 따라 250 일 미만을 제 1 대, $250-259$ 일의 범위를 제 2 대, 260 - 269 일의 범위를 제3대, 270일 이상을 제4대로 구분할 수 있다(Jung and Park, 1986). 본 연구에서는 최근 30년간의 기상자료로 산출된 24지역의 유효천연건조일수를 이용하여 유효천연건조일수대를 구분하고, 이전 30 년간의 기상자료로 구분된 유효천연건조일수 대와 비교하였다.

\section{4. 서울지역의 기상조건에 따른 평형함수율 산출}

초기함수율은 $28-83 \%$ 의 범위이고, 말구지름은 $310-510 \mathrm{~mm}$ 의 범위인 소나무 원목 16 본에 대한 천연건조 중 함수율 변화를 측정하기 위하여 2016년 6월에 서울특별시 동대문구 국립산림과학원 내에 천연건조장을 간이로 설치하였다. 천연건조가 수행된 2016년부터 2018년까지의 월간 평균온도, 상대습도, 풍속와 이에 따른 평형함수율을 산출하였다. 평형함수율은 식(1)의 Hailwood-Horrobin의 흡착모델(Simpson, 1973)을 이용하여 계산하였다.

$$
E M C=\frac{1800}{W}\left(\frac{K h}{1-K h}+\frac{K_{1} K h+2 K_{1} K_{2} K^{2} h^{2}}{1+K_{1} K h+K_{1} K_{2} K^{2} h^{2}}\right)
$$

where, $\mathrm{EMC}=$ equilibrium moisture content $(\%) ; \mathrm{h}=$ relative humidity expressed in decimal form (\%/100); $\mathrm{W}, \mathrm{K}, \mathrm{K}_{1}$, $\mathrm{K}_{2}=$ temperature dependent parameters.

\section{3. 결과 및 고찰}

\section{1. 국내 주요지역의 유효천연건조일수 조사}

Table 1에 국내 24지역의 월별 평균온도, 상대습도, 풍속의 기상인자를 이용하여 1986년에 산출된 월별 평균 유효천연건조일 수, 표준편차, 천연건조 캘린더를 제시하였다(Jung and Park, 1986). 이 값은 지역별로 18 - 30년의 월별 평균 기상인자를 이용하여 계산되었으며, 각각의 측정연도를 Table 1 의 아래에 제시하였다. 국내 24 지역의 평균 유효천연건조일수는 260 일이고, 최대 288일(서귀포), 최소 237일(춘천)이었다. 유효천연건조일수는 평균온도에 영향을 가장 많이 받으며, 상대습도는 9월에 간헐적으로 영향을 미쳤으나, 풍속은 영향을 미치지 않았다.

Table 2에 1988년부터 2017년까지 30년의 월별 평균 기상인자를 근거로 산출된 국내 24지역의 유효천연건조일수를 제시하 였다. 최근 기후온난화에 따른 평균온도의 증가로 Table 1 에 제시된 이전 30 년간의 유효천연건조일수와 비교하여 평균값은 265 일로 약 5 일 증가하였으며, 최대 291일(서귀포), 최소 239일(춘천)이었다. 지역별로 살펴보면 대구지역의 유효천연건조일수 
는 252 일에서 262 일로 10 일이 증가하였으며, 진주지역의 값은 259 일에서 260 일로 1 일이 증가하였다. 6 일 이상 증가한 지역은 수원(6일), 청주(8일), 대전(8일), 추풍령(7일), 포항(6일), 대구(10일), 전주(6일), 울산(6일) 등 이었다. 유효천연건조일수에 영향을 미치는 기상인자는 온도, 상대습도, 풍속의 순서였으며, 풍속에 따른 유효천연건조일수의 공제는 2001년 6월 추풍령지역 과 2013년 6월 울릉도지역에서 각각 1번씩 있었다. 이러한 월별 유효천연건조일수의 차이는 계절별 천연건조 속도변화를 설명할 수 있으며, 각 지역의 천연건조캘린더를 활용하면 목재의 추정천연건조일수를 산정할 수 있다(McMillen, 1978; Jung and Park, 1986).

\section{2. 지역별 유효천연건조일수대 변화}

우리나라의 지역을 1988 년부터 2017년까지 30년간의 기상자료를 이용하여 계산된 지역별 유효천연건조일수에 따라 4 개의 유효천연건조일수대로 구분하면 Table 3과 같이 분류된다. 1986년을 기준으로 1955년부터 1984년까지의 유효천연건조일수대 와 비교하면 제 1 대로 구분되었던 서울, 수원, 대전이 제 2 대로 이동하였고, 제 2 대로 구분되었던 대구, 광주, 진주가 제 3 대로 이동하였으며, 제 3 대로 구분되었던 속초, 포항, 울산이 제4대로 이동하였다. 최근 기후온난화에 따른 평균온도의 증가로 유효천 연건조일수의 평균값이 약 5 일한 것과 같이 유효천연건조일수대도 위도상 북쪽으로 상승하였다. 온도와 강수량에 의해 구별되는 우리나라의 일반적인 기후구분과 달리 주로 온도와 상대습도에 의해 구별되는 유효천연건조일수대는 제4대에 남동해안 지역이 분포하고, 제 3 대에 남부지방과 강릉이 분포하였으며, 내륙지방은 위도에 따라서 제 2 대 및 제1대에 분포하였다.

\section{3. 서울지역의 기상조건과 평형함수율 변화}

기상학적으로 1 년을 3 개월씩 4 계절로 구분하는 것은 태양의 고도와 밤낮의 길이 변화를 반영한 것으로 위도적 보편성이 있으나, 기상이나 기후적인 상태를 고려한 기상학적 계절구분 중 일평균기온을 이용하여 다음과 같이 4 구간으로 구분할 수 있다(Kwon et al., 2007). I) 한랭기간은 일평균기온이 $0^{\circ} \mathrm{C}$ 이하로 설빙이 많다. II) 냉량기간은 일평균기온이 $0-10^{\circ} \mathrm{C}$ 로 가끔 서리가 맺힌다. III) 온난기간은 일평균기온이 $10-20^{\circ} \mathrm{C}$ 로 서리가 없는 기간이다. IV) 서열기간은 일평균기온이 $21^{\circ} \mathrm{C}$ 이상이다. 우리나라는 II-III-IV-I의 4구간이 반복적으로 나타나는 기후조건을 가지고 있으며, 1 년 중 4계절의 변화가 존재한다.

계절의 변화에 따른 유효천연건조일수 및 평형함수율의 변화를 분석하기 위하여 소나무 원목에 대한 천연건조가 수행된 서울지역의 2016년부터 2018년까지의 월간 평균온도, 상대습도, 풍속과 이에 따른 평형함수율을 Table 4에 제시하였다.

최근 3 년간 서울지역의 월간 평균온도, 상대습도, 풍속의 기상인자 중 온도를 기준으로 1,2 월의 한랭기간, 3,12 월의 냉량기간, $4,5,10,11$ 월의 온난기간, $6,7,8,9$ 월의 서열기간으로 구분할 수 있다. 월간 평균온도와 상대습도를 이용하여 산출된 평형함수 율은 온도에 비하여 상대습도의 영향을 많이 받으며, 겨울철에 $10 \%$ 이하로 감소하였다가 점차 증가하여 여름철에 $12.4-14.9 \%$ 까지 상승하였다.

본 연구에서 제시된 서울지역의 월별 평균온도, 상대습도, 풍속의 기상인자는 소나무 원목의 천연건조 중 함수율 변화를 예측하기 위한 기초자료로서 이용될 계획이다. 천연건조 중 함수율 감소를 종속변수하고, 소나무 원목의 초기함수율, 말구지름, 온도, 상대습도, 풍속을 독립변수로 한 다중회귀분석에 적용될 것이며 또한 천연건조 중 소나무 원목의 함수율 예측을 위한 2차원 물질전달의 계수인 수분확산계수와 표면방사계수를 결정하기 위한 자료로 활용될 계획이다.

\section{4. 결 론}

본 연구에서는 소나무 원목의 천연건조 중 함수율 변화를 분석하기 위한 기초자료로 국내 24 지역의 월 평균기온, 상대습도, 풍속 등의 기상인자를 이용하여 유효천연건조일수를 산출하고, 그 결과를 바탕으로 유효천연건조일수대를 구분하였으며, 다음 과 같은 결론을 얻을 수 있었다.

1. 1988 년부터 2017년까지의 30 년간 월별 평균 기상인자를 근거하여 산출된 국내 24 지역에 대한 유효천연건조일수는 239 - 291일의 범위로 평균값은 약 265일이었다. 이 결과는 1986 년을 기준으로 이전 30 년 간의 평균값인 260 일에 비하여 약 5일 증가한 값이다. 유효천연건조일수에 영향을 미치는 기상인자는 온도, 상대습도, 풍속의 순서였으며, 상대습도와 풍속에 의한 일수공제는 매우 적었다.

2. 지역별로 산출된 유효천연건조일수를 이용하여 우리나라를 4 개의 유효천연건조일수대로 구분한 결과, 기후온난화에 따른 평균온도 증가의 영향으로 유효천연건조일수대의 위치가 위도상 북쪽으로 상승하였다.

3. 월별 유효천연건조일수의 차이는 계절별 천연건조 속도변화를 설명할 수 있는 자료되며, 각 지역의 천연건조 캘린더를 활용할 경우 목재의 천연건조일수를 추정하는 것이 가능할 것으로 기대된다. 